\title{
A contextual semi assisted project-based learning (SA-PjBL) about ocean wave energy: Creative thinking of pre-service physics teachers
}

\author{
Muhammad Satriawan 1, a *, Liliasari Liliasari 2, b, Wawan Setiawan 2, c, Ade Gafar Abdullah 2, d, \\ Rosmiati Rosmiati ${ }^{1, \mathrm{e}}$ \\ ${ }^{1}$ STKIP Bima. Jl. Piere Tendean, Mpunda, Bima, Nusa Tenggara Barat, 84111, Indonesia \\ 2 Universitas Pendidikan Indonesia. Jl. Dr. Setiabudi no 229, Bandung 40154, Jawa Barat, Indonesia \\ a satriawan.stkipbima@gmail.com; ${ }^{b}$ liliasari@upi.edu; c wawans@upi.edu; d ade_gaffar@upi.edu; \\ e rosebiru@gmail.com \\ * Corresponding Author.
}

Received: 18 December 2020; Revised: 21 May 2021; Accepted: 20 June 2021

\begin{abstract}
One of the factors that have become an obstacle in the development of technology to use ocean wave energy as a renewable energy source is the lack of human resources who have expertise in this field. Therefore, in the long term, it is necessary to introduce basic knowledge to the young generation about wave energy and other renewable energies and even must equip them with important skills such as creative thinking skills. This study aims to introduce students to how to utilize ocean waves as renewable energy while at the same time developing student creative thinking skills through semiassisted project-based learning. This type of research is weak experiment research with one group pretest-posttest design research. The research was conducted on 31 preservice physics physics teachers who were taking environmental physics lectures at a teacher training university in West Nusa Tenggara. The performance appraisal data were analyzed descriptively while the test result data were analyzed using the $\mathrm{N}$-gain and the Wilcoxon test. Based on the results of data analysis, it was obtained $\langle$ g $\rangle=0.725$, which means that there was a high increase in students' mastery of the concept of using ocean waves as a renewable energy source. In addition, the results of the performance appraisal data (score $>3$ ) indicated that at each stage of learning, students were provided with indicators of creative thinking skills with very satisfied categories. Therefore, it can be concluded that environmental physics lectures using semi-assisted project-based learning able to improve students' mastery of concepts and creative thinking skills.
\end{abstract}

Keywords: Ocean wave energy, Semi-assisted project-based learning, Contextual problems, Concept mastery, Creative thinking skills

How to Cite: Satriawan, M., Liliasari, L., Setiawan, W., Abdullah, A. G., \& Rosmiati, R. (2021). A contextual Semi Assisted Project Based Learning (SA-PJBL) about ocean wave energy: Creative thinking of pre-service physics teachers. Momentum: Physics Education Journal, 5(2), 132-141. https://doi.org/10.21067/mpej.v5i2.5172

\section{Introduction}

Indonesia is one of the countries in the world which has the largest sea area with the secondlongest coast in the world after Canada (Romadhona et al., 2020). This is an advantage for Indonesia in terms of the large potential for ocean energy. Indonesian sea waters along the southern coast of Java to Nusa Tenggara are locations that have a large potential for wave energy ranging from $10-20$ $\mathrm{kW} / \mathrm{m}$ (Rizal et al., 2019). A study has concluded that wave energy at several points in Indonesia can reach up to $70 \mathrm{~kW} / \mathrm{m}$ in several locations (Zikra, 2017). The characteristic of wave energy is very suitable to meet the energy needs of port cities and remote islands in Indonesia. The development of 
wave energy utilization technology in Indonesia, although promising, is still not optimal. High initial installation costs and low efficiency are the biggest obstacles in wave energy projects (Assis et al., 2014). In addition, exploration of ocean wave energy is currently still in its early stages and the wave energy utilization system is only a prototype testing stage (Huynh et al., 2016). Apart from these obstacles, another obstacle faced is the lack of human resources with expertise in this field (Ditjen EBTKE, 2013). Therefore, in the long term, it is very important to introduce the concept of wave energy to the younger generation and teach them basic knowledge, as well as give the younger generation an initial understanding of wave energy and other renewable energies and equip them with important skills such as creative thinking skills.

Environmental Physics course is one of the lectures that can be utilized to deliver the concept of ocean wave energy to students. Through that lectures, of course, provide ample opportunities to learn all things related to environment utilization as renewable energy sources. One thing that can be explored is the use of the environment, especially the ocean environment, as an energy source. So far, environmental physics lectures only contain basic concepts through lectures in class without any field practice, so that students' understanding of the concepts they learn is still low, one example is the concept of wave energy (Satriawan et al., 2019, 2020). In fact, almost all of the materials listed in the environmental physics syllabus are applied physics concepts, which will be easier for students to understand. This happens if the lecture process is not only face-to-face in class but also lectures through practicum, both in the laboratory and in the field or in the environment. In addition, it is based on the observation that environmental physics lectures have only studied the relationship between the environment and physics concepts in general and have not yet taught applied concepts in detail so that students do not have new knowledge as revealed through research. One example is that material on wave energy is not taught in detail how the wave energy converter works, to produce electricity that can be used for everyday life (Penalba et al., 2017; Zhu et al., 2017).

Efforts to introduce renewable energy have been made by several researchers, namely Dinantika et al. (2019) introducing the concept of renewable energy about wind energy through the application of a project-based learning model with an orientation to increase student creative thinking skills; Penalba et al. (2017) teaches the concept of renewable energy about wind energy through a Project-Based Learning Model assisted by concept maps to increase student activity and learning outcomes; O'Mara and Jennings (2001) seeks to introduce the concept of renewable energy about solar energy and wind energy through world wide web technology; Grivokostopoulou et al. (2015) introduced wind energy, heat energy, and solar energy through 3D virtual world techno-logy. Of the several efforts and studies that have been carried out, there is only one study that has a research focus on ocean wave energy, namely research conducted by Huynh et al. (2016), which communicates about ocean wave energy through active learning assisted by wave energy virtual reality system media without having the orientation to develop 21st-century skills of learners. And only one study has attempted to introduce the concept of renewable energy while equipping students with important skills and that is not the concept of ocean wave energy.

Therefore, it is very necessary to innovate and renew in the active learning process that involves students in the process, so that they are able to produce human resources who not only have cognitive insight but also have reliable skills. Project-based learning is a learning model that involves students in problem-solving activities and provides opportunities for students to work autonomously to construct their own learning and ultimately produce real value work products. Project-based learning is able to increase knowledge and skills through product creation through a series of planning, search, and collaboration activities (Bouquet et al., 2017; Goldstein, 2016). Based on this description, the researcher aims to communicate the concept of utilizing ocean wave energy as a renewable energy source while at the same time trying to increase the creative thinking skills of preservice physics teacher students in the hope that these pre-service teachers will teach the concept and equip their students with various important skills when they become teachers. 


\section{Method}

The type of research is experiment research with one-group pretest-posttest design research, which only involves one experimental class. The population of this study was pre-service physics teachers who were taking Environmental Physics lectures in the Physics Education study program at a West Nusa Tenggara university for the 2019/2020 academic year. The samples were determined using the purposive sampling technique, in order to obtain one class consisting of 31 pre-service physics teachers. The instrument used was an essay test of 10 items and a performance appraisal sheet covering process performance and product performance. The questions developed are not only able to measure the mastery of concepts but also can measure student creative thinking skills so that one indicator of student creative thinking skills is measured by two item questions. While the creative thinking skills indicators used are problem sensitivity, fluency, flexibility, originality, and elaboration (Guilford, 1967).

The research was started with a pre-test and then given intervention in the form of project activities and ended with a post-test. Interventions in research are adapted to the phases of projectbased learning with semi-assistance with the Launching the project stage, including identification and defining problems and delivering interesting initial projects and open-ended driving questions; (2) Building knowledge, understanding, and skills; (3) Developing and revising ideas and products include: developing ideas and designs for ocean wave energy converters and developing and revising ocean wave energy converter prototypes; (4) Presenting products and answer to driving questions (Boss et al., 2013). Semi-assisted project-based learning (SA-PjBL) is the provision of assistance to pre-service physics teachers who are facing considerable difficulties and obstacles. Facilitate preservice physics teachers with a variety of supporting tools so that the project time is more efficient. The type of assistance provided by researchers is in the form of questions or clues to the pre-service physics teachers when they conducted the project. This assistance is not structured that given at the beginning of the lesson like scaffolding. This assistance is only given to particular students who have difficulty when solving the problems they face. In this study, pre-service physics teachers are required to produce a product in the form of a prototype ocean wave energy converter as shown in Figure 1.

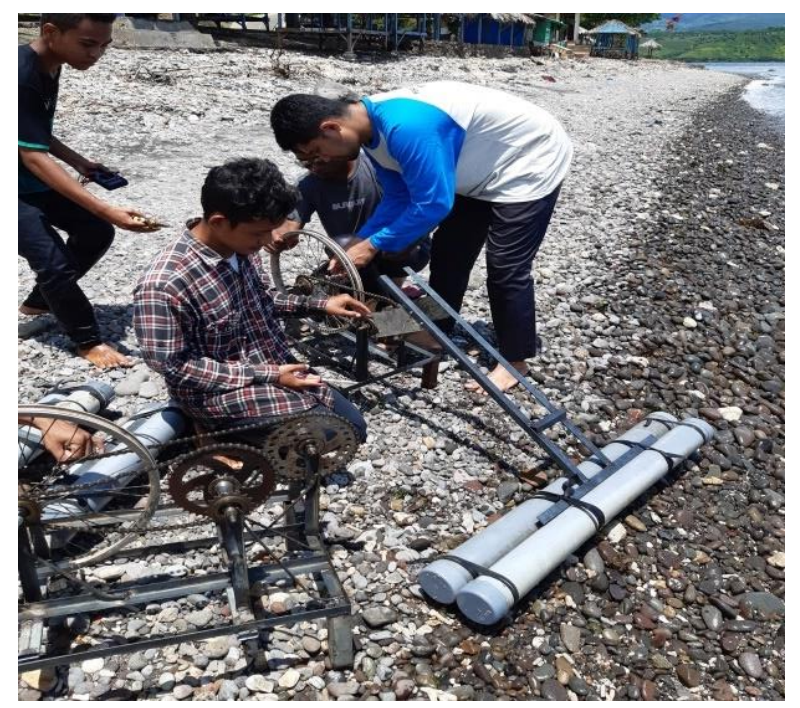

Figure 1. Testing of ocean wave energy converter prototype on the beach

Performance appraisal data were analyzed descriptively, the maximum score given for each task item was 4 with information, 4 is very satisfying, 3 is satisfying, 2 is partly satisfying, and 1 is not satisfying. While the data of essay test result were analyzed using a normalized gain score ( $\mathrm{N}$-gain) to determine the increase in concept mastery and creative thinking skills of pre-service physics teachers regarding the topic of using ocean wave energy as a renewable energy source. The $\mathrm{N}$-gain score can be calculated using the Formula 1 (Hake, 1998). 


$$
\langle g\rangle=\frac{s_{\text {post }}-S_{\text {pre }}}{S_{m-\text { ideal }}-S_{\text {Pre }}}
$$

Where, $\langle g\rangle$ is Normalized Average N-gain score; $S_{\text {post }}$ is Post-test average score; $S_{\text {pre }}$ is Pretest average score; and $S_{m \text {-ideal }}$ is Ideal maximum score. The $\mathrm{N}$-gain average value that has been obtained is then interpreted based on Table 1.

Table 1. Interpretation of average N-gain score

\begin{tabular}{cc}
\hline$<\mathrm{g}>$ Value & Criteria \\
\hline$<\mathrm{g}>\geq 0,70$ & High \\
$0.30 \leq<\mathrm{g}><0,70$ & Middle \\
$\langle\mathrm{g}\rangle\langle 0,30$ & Low \\
\hline
\end{tabular}

Before testing the hypothesis, the normality test was performed as a prerequisite test. The normality test used was the Kolmogorov-Smirnova test. Furthermore, to determine the effect of the learning model on increasing concept mastery, a statistical test in the form of a non-parametric test (Wilcoxon Test) was carried out using the SPSS 25 application program. In this test, the significance level $(\alpha)$ used was 0.05 or $5 \%$. The hypotheses in this study are (1) null hypothesis (Ho) namely there is no difference in students' mastery of concepts before and after attending environmental physics lectures; (2) alternative hypothesis $(\mathrm{Ha})$ namely there is differences in students' mastery of concepts before and after attending environmental physics lectures. The criteria for this test decision are: if Sig. (2-tailed) $<0.05$, Ho rejected and otherwise if Sig. (2-tailed) $>0.05$, Ho received.

\section{Results and Discussion}

Project-based learning is more than just a project because it investigates and responds to authentic, interesting, and complex problems with a deep and sustainable concern. This has a positive impact on pre-service physics teachers, one of which is being able to increase their mastery of concepts in the material being taught. Likewise, the results expressed in this study, where through project-based learning with semi-assistance and oriented to contextual problems can improve mastery of the concept of utilizing ocean wave energy as renewable energy as shown in Table 2.

Table 2. Summary of mastery concept data analysis

\begin{tabular}{|c|c|c|c|c|c|c|c|}
\hline \multirow{2}{*}{ Aspect } & & \multirow{2}{*}{$\begin{array}{l}\text { Average } \\
\text { Scores }\end{array}$} & \multicolumn{2}{|c|}{$\begin{array}{c}\text { Normality test } \\
\text { (Kolmogorov-Smirnova) }\end{array}$} & \multirow{2}{*}{$\begin{array}{c}\text { (Wilcoxon Test) } \\
\text { Asymp. Sig. } \\
\text { (2-tailed) }(\alpha)\end{array}$} & \multicolumn{2}{|c|}{$\mathrm{N}$-gain } \\
\hline & & & Sig. $(\alpha)$ & Decision & & $\mathrm{N}-\mathrm{g}$ & Category \\
\hline \multirow{2}{*}{ Creative thinking skills } & Pre-Test & 18.06 & $\alpha=0.200$ & \multirow{2}{*}{ Abnormal } & \multirow{2}{*}{$\alpha=0.000$} & \multirow{2}{*}{0.725} & \multirow{2}{*}{ High } \\
\hline & Post-Test & 77.14 & $\alpha=0.000$ & & & & \\
\hline
\end{tabular}

Based on the results of data analysis in Table 2, the average value of pre-service physics teachers after taking environmental physics lectures has a large enough difference between the pre-test and post-test scores. This means that through environmental physics lectures, pre-service physics teachers who initially had low knowledge of the use of ocean wave energy, but after attending environmental physics lectures pre-service physics teachers have a fairly high understanding of the use of ocean wave energy as a renewable energy source. This is also confirmed by other data in Table 1 where the Asymp value. Sig. (2-tailed) on the Wilcoxon test shown that there was a significant effect on the use of SA-PjBL learning model on increasing pre-service physics teachers' mastery of concepts about the use of ocean waves as renewable energy. In addition, Table 1 also presents an average $\mathrm{N}$-gain score above 0.7 which indicates that there was an increase in concept mastery in the high category. These findings were different from those found by (Satriawan et al., 2019, 2020) that mastery of the concept of ocean wave energy for pre-service physics teachers after attending environmental physics lectures with conventional learning model at the same study program and university in the previous academic year generation was still relatively low. This shows that the SA$\mathrm{PjBL}$ learning model used in this study has a positive contribution to improving student mastery of 
concepts related to the concept of ocean wave energy. Besides that, based on the results of the questionnaire filled out by pre-service physics teachers, the majority of them agreed that the SA-PjBL model was effective because not only being able to create a pleasant learning situation but also facilitated students in developing 21st-century skills.

In addition, the efforts made by pre-service physics teachers during the lecture process to increase creative thinking skills in the five indicators has recorded in assignment answers, worksheets, and observation sheets during the lecture process. On the problem sensitivity indicator, pre-service physics teacher have been able to identify national energy problems in discourse and find various solutions. They have also been able to analyze driving questions and project assignments to identify what needs to be known and review it from different points of view regarding the topic of investigation (Aydin, 2016; Boss et al., 2013; Yilmaz \& Turkmen, 2013). In addition, pre-service physics teachers have also been able to formulate relevant and varied problems based on the problems they know. On the indicators of fluency, pre-service physics teachers have been able to formulate various and relevant project work objectives. They are also able to formulate relevant and varied problems based on the problems they know (Arreola \& Reiter-Palmon, 2016; Mumford et al., 2020). When preservice physics teachers have difficulty in obtaining tools and materials, they use alternative materials that are relevant to the project they are working on without reducing the performance of the resulting product. In the indicator of flexibility, pre-service physics teachers have been able to ask driving questions and project assignments to be done. They have also been able to analyze the weaknesses and bad possibilities that will occur if they do the same thing during project work based on the results of these trials as a benchmark for project development. In addition, pre-service physics teachers were also able to provide problem solution that they faced by collaboration in the group (Satriawan et al., 2020).

On the indicator of originality, pre-service physics teachers have been able to propose various unique ideas related to the technology of utilizing ocean wave energy which was developed and its working principles in brief. They are also able to design unique product sketches so that the resulting products are diverse (Rahardjanto et al., 2019). And also when presenting project results, they do it in a unique way and maintain every statement that is conveyed. In the elaboration indicator, preservice physics teachers have been able to elaborate on the latest data related to the state of conventional energy sources, about the geographical location of Indonesia which is an archipelago and the use of ocean energy as an unlimited source of energy and the potential of the Indonesian sea as a source of renewable energy. Pre-service physics teachers have also been able to describe detailed and relevant experimental procedures. In addition, they are also able to express the importance of the project you will be working on in detail. And also they are able to describe project procedures in detail and are relevant to the objectives, able to compile a detailed project work schedule, able to compile data retrieval procedures for conducting trials, and able to analyze data to determine the power efficiency generated by the prototype.

Pre-service physics teachers' creative thinking skills have been equipped during the environmental physics lecture process reinforced by data on the results of process performance appraisals collected through assignment sheets, LKM and observation sheets as shown in Figure 2. Based on the graph in Figure 2 that creative thinking skill at the each stage of learning is in the satisfactory category with a score above 3 . This shown that creative thinking skill is successfully equipped at every stage of learning.

At the stage of launching the project, the average score obtained by pre-service physics teachers with categorized as satisfactory. This happens because pre-service physics teachers have been able to elaborate on the latest data related to the state of conventional energy sources, about the geographical location of Indonesia which is an archipelago and the use of ocean energy as an unlimited source of energy and the potential of the Indonesian sea as a source of renewable energy. In addition, pre-service physics teachers are able to identify national energy problems in discourse and find various solutions, be able to ask driving questions and project assignments to be carried out. Besides that, they are able to analyze driving questions and project assignments to identify what needs to be known and review it from various points of view related to the topic of investigation. In 
line with what (Billah et al., 2019; Gradaleva \& Polukhina, 2020) expressed that at the launching project stage in project-based learning students can be equipped with the ability to analyze and investigate various problems on the topics presented. At the stage of building knowledge, understanding and skills that the average score obtained by pre-service physics teachers with the satisfactory category. This happens because pre-service physics teachers have been able to formulate diverse and relevant experimental objectives to the topic, were able to determine alternative tools and materials during experimental activities prior to project work. The ability in thinking of alternatives is an indicator that they are in a creative thinking process (Kim, 2019; Mumford, 2003; Mumford et al., 2020). In addition, they were also able to describe experimental procedures in detail and relevant, analyze weaknesses and the bad possibilities that will happen if they do the same thing during project work based on the results of the trial as a benchmark for project development.

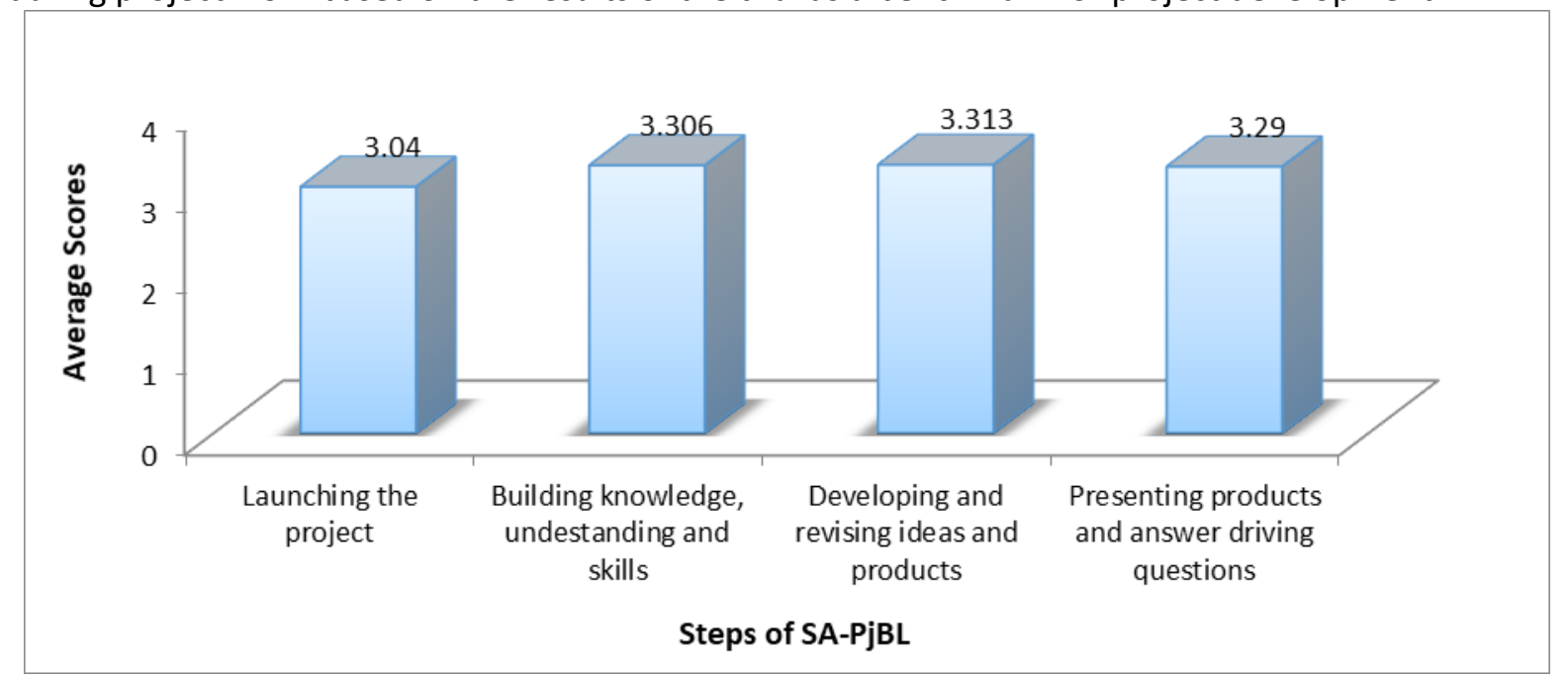

Figure 2. The results of the performance assessment of the creative thinking skills process

At the stage of developing and revising ideas and products, the average score obtained by preservice physics teachers with the satisfactory category. This happens because pre-service physics teachers have been able to propose various unique ideas related to the use of ocean wave energy which will be developed and its working principles briefly. Pre-service physics teachers were also able to formulate relevant and diverse problems according to the project topic being carried out according to the knowledge they known (Devkota et al., 2017; Sasson et al., 2018). In addition, they were also able to formulate objectives that are relevant to the problem posed and express the importance of the project you will be working on in detail. When they have difficulty obtaining tools and materials, they immediately use the relevant alternative materials. Before making a product they describe the project procedure in detail and are relevant to the goal, design a unique sketch for reference making the product, and compile a detailed project work schedule. And after producing the product, pre-service physics teachers compile their own data retrieval procedures to conduct trials and analyze data to determine the efficiency of the power generated by the prototype.

At the stage of presenting the product and answering driving questions, the average score obtained by pre-service physics teachers with the satisfactory category. This happens because preservice physics teachers have been able to present project results in a unique way and maintain every statement submitted. When other participants asked unique questions, the pre-service physics teachers who made the presentation answered all the questions. The other hands, they have even been able to provide input to solve problems faced by other groups. In this stage, some researchers agreed that the indicators of creative thinking skills that can be trained were the ability of students to present the products, taken responsibility for the products, and found the answers to problems that have been identified at the beginning of the project creatively (Anazifa \& Djukri, 2017; Huynh et al., 2016; Sasson et al., 2018; Uziak, 2016). 


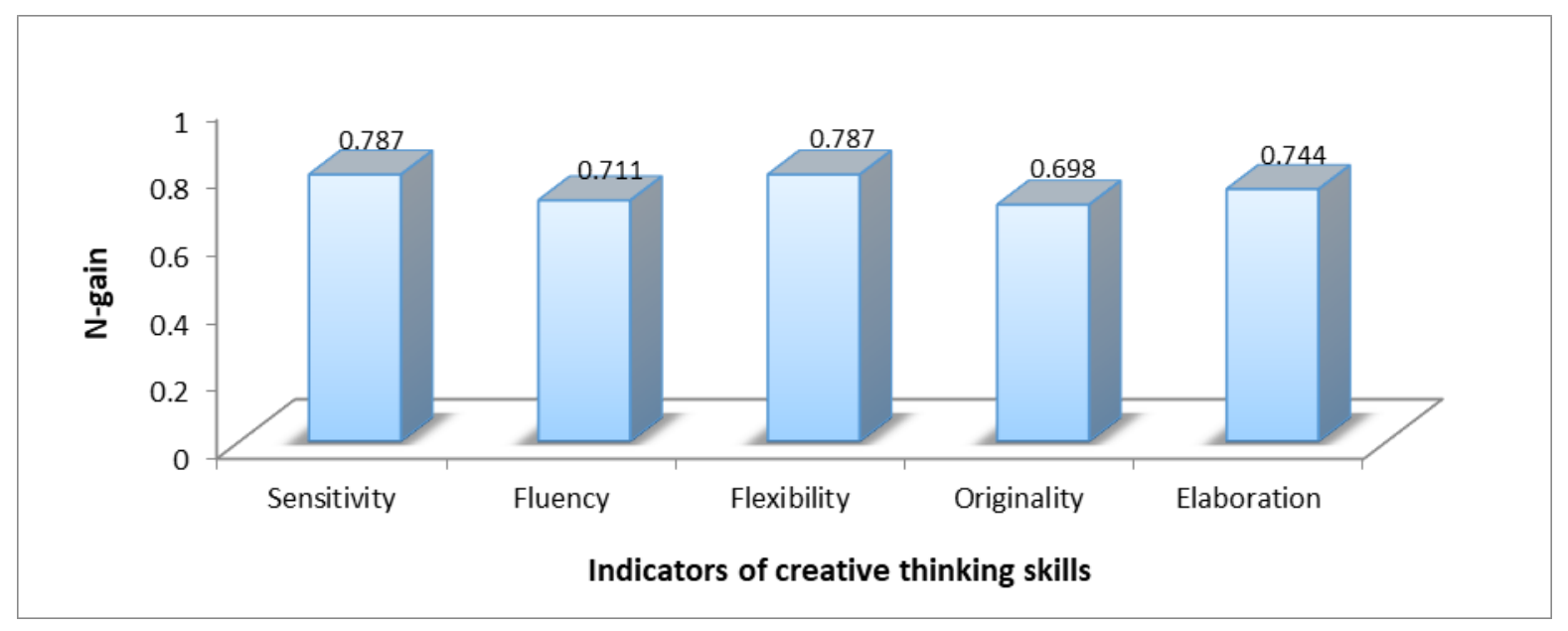

Figure 3. Increasing pre-service physics' creative thinking skills data

Evidence that strengthens that the success of creative thinking skills was equipped through SA$\mathrm{PjBL}$ is the $\mathrm{N}$-gain data shown in Figure 3. Based on the $\mathrm{N}$-gain graph obtained from the pre-test and post-test values of creative thinking skills in Figure 3 that the average $\mathrm{N}$-gain of creative thinking skills is in the high category. Meanwhile, if viewed from each indicator that of the 5 indicators of creative thinking skills, there is only one indicator that has $\mathrm{N}$-gain in the medium category, namely the originality indicator. This is because pre-service physics teachers have not maximally come up with ideas in ways that are original, new, unique, and rarely given by most people, have a strong will to complete tasks (Cotter et al., 2020; Dumas \& Runco, 2018; Scheffer et al., 2017).

Meanwhile, the high increase in pre-service physics teacher creative thinking skills is due to the fact that pre-service physics teachers have various indicators of creative thinking skills that can be seen from assignment sheets, LKM, observation sheets and tests of creative thinking skills. In the sensitivity indicator, pre-service physics teachers have been able to detect, recognize and understand a problem, be able to respond to a statement, and be able to find opportunities (Huynh et al., 2016). On the indicators of fluency, pre-service physics teachers have been able to generate many ideas, answers, problem solving or questions, are able to provide many ways or suggestions for doing various things (Khoiri et al., 2017; Wijayati et al., 2019). On the indicators of flexibility, pre-service physics teachers have been able to put forward various solutions or approaches to problems, produce various ideas or questions, are able to see a problem from different points of view (Bryndin, 2019; Kenett et al., 2018; Li et al., 2020). In the elaboration indicator, pre-service physics teachers have been able to add to a situation or problem so that it becomes complete, and detail it in detail, be able to respond to questions passionately, be active and enthusiastic in completing assignments, and are able to add or detail an idea so as to improve the quality of ideas (Kharkhurin \& Yagolkovskiy, 2019; Maio et al., 2020). Based on these findings, the learning model used in environmental physics lectures about wave energy and it's utilize as a renewable energy source has been successful in increasing pre-service physics teachers' creative thinking skills.

\section{Conclusion}

Based on the results of the research and discussion above, it can be concluded that environmental physics lectures through SA-PjBL can improve pre-service physics teachers' conceptual mastery of the use of ocean wave energy as a renewable energy source. In addition, through lectures by using SA-PjBL, it can also increase pre-service physics teachers' creative thinking skill which is indicated by the $\mathrm{N}$-gain value on each creative thinking skills indicator where the average $\mathrm{N}$-gain value is above 0.7 . This is also evidenced by the uniqueness of the wave energy converter prototype that produced from their project was conducted. Besides that, through using SA-PjBL, each stage of learning pre-service physics teachers was equipped with indicators of creative thinking skills with satisfactory categories. Recommendations for further research, through semi-assisted project-based 
learning and contextual project themes aimed at developing other important skills in the form of critical thinking skills, communication, collaboration and creative thinking skills simultaneously.

\section{Acknowledgment}

The Authors would like to thanks to RISTEK DIKTI has founded this research in a doctoral dissertation research grant with contract number 548/UN40.D/PT/2020. And the second, the authors also like to everybody who have participated in this research and the staff who has given the chance to conduct this research.

\section{References}

Anazifa, R. D., \& Djukri, D. (2017). Project-based learning and problem-based learning: Are they effective to improve student's thinking skills? Jurnal Pendidikan IPA Indonesia, 6(2), 346. https://doi.org/10.15294/jpii.v6i2.11100

Arreola, N. J., \& Reiter-Palmon, R. (2016). The effect of problem construction creativity on solution creativity across multiple everyday problems. Psychology of Aesthetics, Creativity, and the Arts, 10(3), 287-295. https://doi.org/10.1037/a0040389

Assis, L. E., Beluco, A., \& De Almeida, L. E. (2014). On the wave energy potential along the southern coast of Brazil. International Journal Of Energy and Environment, 5(2), 59-66.

Aydin, M. (2016). Exploring pre-service science teacher methods and strategies for the driving questions in research inquiry: From consulting an instructor to group discussion. International Journal of Environmental and Science Education, 11(5), 559-570. https://doi.org/10.12973/ijese.2016.404a

Billah, A., Khasanah, U., \& Widoretno, S. (2019). Empowering higher-order thinking through projectbased learning: A conceptual framework. AIP Conference Proceedings, 2194(December). https://doi.org/10.1063/1.5139743

Boss, S., Larmer, J., \& Mergendoller, J. R. (2013). PBL for 21st century success: Teaching critical thinking, collaboration, communication, and creativity. Buck Institute for Education.

Bouquet, F., Bobroff, J., Fuchs-Gallezot, M., \& Maurines, L. (2017). Project-based physics labs using low-cost open-source hardware. American Journal of Physics, 85(3), 216-222. https://doi.org/10.1119/1.4972043

Bryndin, E. (2019). Creative innovative higher education of researchers with flexible skills and synergy of cooperation. Contemporary Research in Education and English Language Teaching, 1(1), 16. https://doi.org/10.33094/26410230.2019.11.1.6

Cotter, K. N., Ivcevic, Z., \& Moeller, J. (2020). Person-oriented profiles of originality and fluency in divergent thinking responses. Journal of Research in Personality, 86, 103941. https://doi.org/10.1016/j.jrp.2020.103941

Devkota, S. P., Giri, D. R., \& Bagale, S. (2017). Developing 21st century skills through project-based learning in EFL context: challenges and opportunities. The Online Journal of New Horizons in Education, 7(1), 47-52. http://www.tojdel.net/journals/tojned/volumes/tojned-volume07i01.pdf\#page $=54$

Dinantika, H. K., Suyanto, E., \& Nyeneng, I. D. P. (2019). Pengaruh penerapan model pembelajaran project based learning terhadap kreativitas siswa pada materi energi terbarukan. Titian IImu: Jurnal Ilmiah Multi Sciences, 11(2), 73-80. https://doi.org/10.30599/jti.v11i2.473

Ditjen EBTKE. (2013). Statistik EBTKE 2013. Direktorat Jenderal Energi Baru, Terbarukan, dan Konservasi Energi, Kementerian Energi dan Sumber Daya Mineral.

Dumas, D., \& Runco, M. (2018). Objectively scoring divergent thinking tests for originality: A reanalysis and extension. Creativity Research Journal, 30(4), 466-468. https://doi.org/10.1080/10400419.2018.1544601 
Goldstein, O. (2016). A project-based learning approach to teaching physics for pre-service elementary school teacher education students. Cogent Education, 3(1), 1-12. https://doi.org/10.1080/2331186X.2016.1200833

Gradaleva, E., \& Polukhina, M. (2020). Development of a professional training course to enhance pjbl competencies of teachers at a technical university. SOCIETY. INTEGRATION. EDUCATION. Proceedings of the International Scientific Conference, 1, 169. https://doi.org/10.17770/sie2020vol1.4810

Grivokostopoulou, F., Perikos, I., Konstantinos, K., \& Hatzilygeroudis, I. (2015). Teaching renewable energy sources using 3D virtual world technology. 2015 IEEE 15th International Conference on Advanced Learning Technologies, 472-474. https://doi.org/10.1109/ICALT.2015.126

Guilford, J. P. (1967). The nature of human intelligence. McGraw-Hill.

Hake, R. R. (1998). Interactive-engagement versus traditional methods: A six-thousand-student survey of mechanics test data for introductory physics courses. American Journal of Physics, 66(1), 64-74. https://doi.org/10.1119/1.18809

Huynh, T., Hou, G., \& Wang, J. (2016). Communicating wave energy: An active learning experience for students. American Journal of Engineering Education (AJEE), 7(1), 37-46. https://doi.org/10.19030/ajee.v7i1.9684

Kenett, Y. N., Levy, O., Kenett, D. Y., Stanley, H. E., Faust, M., \& Havlin, S. (2018). Flexibility of thought in high creative individuals represented by percolation analysis. Proceedings of the National Academy of Sciences of the United States of America, 115(5), 867-872. https://doi.org/10.1073/pnas.1717362115

Kharkhurin, A. V., \& Yagolkovskiy, S. R. (2019). Preference for complexity and asymmetry contributes to elaboration in divergent thinking. Creativity Research Journal, 31(3), 342-348. https://doi.org/10.1080/10400419.2019.1641687

Khoiri, N., Riyadi, S., Kaltsum, U., Hindarto, N., \& Rusilawati, A. (2017). Teaching creative thinking skills with laboratory work. International Journal of Science and Applied Science: Conference Series, 2(1), 256. https://doi.org/10.20961/ijsascs.v2i1.16722

Kim, K. H. (2019). Demystifying creativity: What creativity isn't and is? Roeper Review, 41(2), 119128. https://doi.org/10.1080/02783193.2019.1585397

Li, J., Orlov, N., Wang, Z., Jiao, B., Wang, Y., Xu, H., Yang, H., Huang, Y., Sun, Y., Zhang, P., Yu, R., Liu, M., \& Zhang, D. (2020). Flexible reconfiguration of functional brain networks as a potential neural mechanism of creativity. Brain Imaging and Behavior. https://doi.org/10.1007/s11682020-00388-2

Maio, S., Dumas, D., Organisciak, P., \& Runco, M. (2020). Is the reliability of objective originality scores confounded by elaboration? Creativity Research Journal, 32(3), 201-205. https://doi.org/10.1080/10400419.2020.1818492

Mumford, M. D. (2003). Where have we been, where are we going? Taking stock in creativity research. Creativity Research Journal, 15(2-3), 107-120. https://doi.org/10.1080/10400419.2003.9651403

Mumford, M. D., Martin, R., Elliott, S., \& McIntosh, T. (2020). Creative failure: Why can't people solve creative problems. The Journal of Creative Behavior, 54(2), 378-394. https://doi.org/10.1002/jocb.372

O'Mara, K. L., \& Jennings, P. J. (2001). Innovative renewable energy education using the World Wide Web. Renewable Energy, 22(1-3), 135-141. https://doi.org/10.1016/S0960-1481(00)00048-3

Penalba, M., Cortajarena, J. A., \& Ringwood, J. V. (2017). Validating a wave-to-wire model for a wave energy converter-part II: The electrical system. Energies, 10(7), 1-24. https://doi.org/10.3390/en10071002

Rahardjanto, A., Husamah, \& Fauzi, A. (2019). Hybrid-PjBL: Learning outcomes, creative thinking 
skills, and learning motivation of preservice teacher. International Journal of Instruction, 12(2), 179-192. https://doi.org/10.29333/iji.2019.12212a

Rizal, A. M., Ningsih, N. S., Sofian, I., Hanifah, F., \& Sofian, I. (2019). Preliminary study of wave energy resource assessment and its seasonal variation along the southern coasts of Java, Bali, and Nusa Tenggara waters. Journal of Renewable and Sustainable Energy, 014502(11). https://doi.org/10.1063/1.5034161

Romadhona, S., Mutmainnah, L., Wibowo, C., \& Setiawati, T. C. (2020). "Assessment of coastal vulnerability index on potential agricultural land - CVI, Banyuwangi Regency." E3S Web of Conferences, 142, 01002. https://doi.org/10.1051/e3sconf/202014201002

Sasson, I., Yehuda, I., \& Malkinson, N. (2018). Fostering the skills of critical thinking and questionposing in a project-based learning environment. Thinking Skills and Creativity, 29, 203-212. https://doi.org/10.1016/j.tsc.2018.08.001

Satriawan, M., Liliasari, S., \& Setiawan, W. (2019). Wave energy concept mastery relate on creative thinking skills of the pre-service physics teachers in environmental physics lectures. Journal of Physics: Conference Series, 1157(3). https://doi.org/10.1088/1742-6596/1157/3/032044

Satriawan, M., Liliasari, Setiawan, W., \& Abdullah, A. G. (2020). Analysing of pre-service physics teachers critical thinking skills profile in ocean wave energy topic. Journal of Physics: Conference Series, 1521(2). https://doi.org/10.1088/1742-6596/1521/2/022041

Scheffer, M., Baas, M., \& Bjordam, T. K. (2017). Teaching originality? Common habits behind creative production in science and arts. Ecology and Society, 22(2), art29. https://doi.org/10.5751/ES09258-220229

Uziak, J. (2016). A project-based learning approach in an engineering curriculum. Global Journal of Engineering Education, 18(2), 119-123. http://www.wiete.com.au/journals/GJEE/Publish/vol18no2/12-Uziak-J.pdf

Wijayati, N., Sumarni, W., \& Supanti, S. (2019). Improving student creative thinking skills through project based learning. KnE Social Sciences, 2019, 408-421. https://doi.org/10.18502/kss.v3i18.4732

Yilmaz, C., \& Turkmen, N. (2013). An investigation of the effect of project-based learning approach on children's achievement and attitude in science. The Online Journal of Science and Technology, $3(2), 9-17$.

Zhu, Y. M., Luo, Z. R., Lu, Z. Y., \& Shang, J. Z. (2017). Modeling and experiment of a novel micro wave energy converter. Applied Mechanics and Materials, 863, 175-182. https://doi.org/10.4028/www.scientific.net/AMM.863.175

Zikra, M. (2017). Preliminary assessment of wave energy potential around Indonesia Sea. Applied Mechanics and Materials, 862, 55-60.

https://doi.org/10.4028/www.scientific.net/AMM.862.55 